\title{
Doğuştan çarpık ayak (pes equino varus)
}

\author{
Congenital club foot
}

\author{
Ahmet Us, Ali Turgut \\ Tepecik Eğitim ve Araştırma Hastanesi, Ortopedi ve Travmatoloji Kliniği, İzmir
}

\begin{abstract}
Doğuştan çarpık ayak (DÇA), 1-2/1000 canlı doğumda karşılaşılan, belki de yoğun tedavi gerektiren en sık doğumsal ortopedik anormalliktir. Bu hastalıkta diz altındaki bütün kas-iskelet sistemi yapıları displastiktir. DÇA; gebelik esnasında ayak duruşuna bağlı pozisyonel olabileceği gibi artrogripozis, miyelodisplazi, Streeter displazisi, Freeman Sheldon sendromu, Möbius sendromu, Down Sendrom'u gibi konjenital ve nöropatik hastalıklara eşlik de edebilir. Ancak, en sık görülen şekli idiyopatik DÇA'dır. Tanı, intrauterin 12. haftadan itibaren ultrasonografi ile de konulabileceği gibi, doğum sonrası klinik muayene ile kolaylıkla konur. Tedaviye yenidoğan döneminde mümkün olan en erken zamanda başlanmalıdır. Ailelerin hastalık ve tedavi konusunda eğitilmesi tedaviye uyumu arttırmakta ve olası nükslerin önüne geçebilmektedir. Günümüzde konservatif tedaviyle çok iyi sonuçlar elde edilmekte olup, cerrahi tedavi rezidü ya da nüks deformite varlığında tercih edilmektedir. Konservatif tedavide en çok kullanılan yöntemler Ponseti yöntemi ve Fransız fizyoterapi yöntemidir. Cerrahi tedavide ise çeşitli yumuşak doku gevşetmeleri ve kemik ameliyatları kullanılmaktadır. Tedavideki temel amaç; yere düz basan, ağrısız ve fonksiyonel bir ayak elde etmektir.
\end{abstract}

Anahtar sözcükler: pes ekinovarus; çarpık ayak; Ponseti yöntemi; Fransız fizyoterapi yöntemi; konservatif tedavi; cerrahi tedavi

\begin{abstract}
Congenital clubfoot is probably the most common (1-2 in 1000 live births) orthopaedic anomaly requiring intensive treatment. It represents dysplasia of all musculoskeletal and neurovascular structures distal to the knee. It may be positional because of intrauterine position of the feet during pregnancy or it may be associated with conditions such as arthrogriposis, myelodysplasia, Streeter's dysplasia, Freeman Sheldon syndrome, Möbius syndrome and Down syndrome. However, most common presentation is idiopathic clubfoot in an otherwise normal infant. It can as well as be diagnosed with maternal ultrasound starting from 12. week of the pregnancy or with physical examination after birth. Treatment of the newborn should be started as early as possible. Parental education about the disease and course of the treatment improves compliance and prevents possible recurrences. At present, excellent results can be achieved with conservative methods, thus surgical treatment should be reserved for residual or recurrent deformities. In conservative treatment, respectively, Ponseti method and French functional method are used most commonly. Surgically, various soft tissue releases and bony procedures may be performed. Main goal in the treatment is to obtain plantigrade, functional and pain-free feet.
\end{abstract}

Key words: pes equino varus; clubfoot; Ponseti method; French functional method; conservative treatment; surgical treatment
D oğuştan çarpık ayak (DÇA), 1-2/1000 canlı doğumda karşılaşılan, belki de yoğun tedavi gerektiren en sık doğumsal ortopedik anormalliktir. ${ }^{[1]}$ Bu hastalıkta diz altındaki bütün kas-iskelet sistemi yapıları displastiktir. Bu displazinin en önemli belirteçlerinden birisi, şüphesiz, uygun tedavi edilmiş olan hastalarda bile normal ayağın oluşmasının sağlanamamasıdır. ${ }^{[2,3]}$ Erkek cinsiyette belirgin olarak daha sık görülmektedir (2-4/1000). ${ }^{[4]}$ iki taraflı tutulum hastaların yarısında gözlenmekte olup, tek taraflı olanda sağ ayağın daha sık tutulduğu bildirilmiştir. ${ }^{[5]}$

\section{NORMAL AYAK GELişiMi}

Bernhart'ın 1988 yılında yapmış olduğu çalışma, intrauterin dönemde ayak gelişiminin anlaşılması açısından oldukça önemlidir. ${ }^{[6]}$ Gebeliğin 4 . haftasında, alt ekstremite tomurcuğu fetüste belirmeye başlar. Altıncı haftada alt ekstremite çıkıntıları gövdeye dik haldedir ve oluklar halinde bölümlere ayrılmalar başlar. Yedinci haftada, ayaklar tabanları birbirine bakacak şekilde dönmüştür. Sekizinci haftada ayaklar ekinde, ayak önü adduksiyondadır. Dokuzuncu ve onikinci haftalar

- Iletişim adresi: Doç. Dr. Ali Turgut, Tepecik Eğitim ve Araştırma Hastanesi, İzmir Tel: 0537 - 0274425 e-posta: draliturgutort@yahoo.com.tr

- Geliș tarihi: 17 Kasım 2017 Kabul tarihi: 17 Kasım 2017 
arasında ayaklar supinasyon pozisyonuna dönerlerken, 2-5. metatarsların adduksiyonu azalır. Onüçüncü ve onaltıncı haftalar arasında ayakların ekin pozisyonları azalmaya başlar. Onyedinci ve yirminci haftalar arasında alt ekstremiteler intrauterin dönemdeki nihai uzunluklarına erişmiştir; ayaklar pronasyona dönmeye başlar. Yirmisekizinci haftada artık ayak nötral pozisyondadır. ${ }^{6]}$

\section{ETIYOLOJi}

DÇA; gebelik esnasında ayak duruşuna bağlı pozisyonel olabileceği gibi, artrogripozis, miyelodisplazi, Streeter displazisi, Freeman Sheldon sendromu, Möbius sendromu, Down sendromu gibi konjenital ve nöropatik hastalıklara da eşlik edebilir. Ancak en sık görülme şekli, eşlik eden herhangi bir deformitenin olmadığı idiyopatik tiptir. ${ }^{[1,7]}$

DÇA etiyolojisinde; birincil embriyonik mezenkimal bozukluk, talusun beslenme bozukluğu, anormal kas yapışmaları, genetik bozukluklar, ayağın intrauterin dönemdeki gelişmesinde duraklama (böylece ayağın nötrale gelememesi) gibi birçok faktör suçlanmıştır. ${ }^{\left[{ }^{[811]}\right.}$ Zimny ve ark., ayak bileği mediyalindeki bağlarda myofibroblastik dokuda artış olduğunu saptamışlardır. ${ }^{[12]}$ DÇA'da saptanan bu kontrakte dokularda; Değiştirici Büyüme Faktörü b (TGF- $\beta$ ) ve Trombosit Kaynaklı Büyüme Faktörü (PDGF) düzeylerinin diğer dokulara oranla daha yüksek düzeyde oldukları saptanmıştır. ${ }^{[13]}$ ilgili ayaklardaki sinoviyal dokuda sinir liflerinin azaldığı ve buna bağlı olarak duyusal bozukluk sonucunda fibrozis ve gerginlik oluşabileceği bildirilmiştir. ${ }^{[14]}$ Talusun gelişiminde birincil plazma germ defekti olduğu da varsayımlar içindedir. ${ }^{[15,16]}$ DÇA'lı hastaların kas lifleri de incelenmiş ve önceleri triceps surae ve peroneal tendonlarda Tip 1 kas lifi atrofisi olduğu öne sürülmüştür..$^{[1,17,18]}$ Ancak, daha güncel araştırmalarda çoğu hastada kasta yapısal anormallik olmadığı saptanmıştır. ${ }^{[19]}$ Monozigotik ikizlerde \%32,5'a kadar görülebilen konkordans, genetik geçişin etiyolojide önemli bir etken olduğunu düşündürmektedir. ${ }^{[20]}$

\section{DÇA'da ayak}

DÇA deformitesinde temel olarak; ayak ortası Kavusu, ayak önü Adduktusu, ayak arkası Varusu ve ayak arkası Ekini (KAVE) izlenmektedir. ${ }^{[7]}$ Ayak inversiyonda ve supinasyondadır. Ayak önü, ayak ortası ve arkasına göre adduksiyon ve pronasyondadır. Kavus görünümünün nedeni, ayak önünün ayak arkasına göre pronasyonda olmasıdır.

Deformitenin en önemli bileşenlerinden birisi, deforme talusun altında kalkaneus-navikula ve küboid kemiğin mediyal ve plantara doğru yer değiştirmesidir. Talus boynu kısalmış ve mediyal-plantara dönmüştür. ${ }^{[21,22]}$ Kalkaneusun distal ucunda varus deformitesi mevcuttur, sustentakulum tali gelişme geriliği göstermektedir.[23-25] Kalkaneus aşağıya ve içe doğru dönmüştür, böylece ön-arka ve yan planda talus ve kalkaneus paralelleşmiştir. Kalkaneusun arka kısmı ve fibula arasında kalkaneofibuler bağ oldukça gergindir. Bazı olgularda küboid kemik kalkaneusun önünden mediyale doğru sublukse olmuş olabilir. ${ }^{[26]}$ Plantar fasya, kısa plantar kaslar, plantar kalkaneo-naviküler bağ (spring bağ) kısalmıştır. Aşil, tibialis posterior, fleksör dijitorum longus, fleksör hallusis longus tendonları kısalmıştır. Ayak bileği ekleminin ve talokalkaneal eklemin arka kapsülleri gergindir. Ayağın şiddetli varusu ve adduksiyonu sonucu naviküla kemiği mediyal malleole oldukça yaklaşmış olabilir. İnternal tibial torsiyonun eşlik edip etmemesi konusunda birbirine karşıt çalışmalar mevcuttur. ${ }^{[1]} \mathrm{Bu}$ hastaları tedavi eden hekimin bilmesi gereken önemli hususlardan birisi de olası damarsal anormalliklerdir. Bu hastaların çoğunda, dorsalis pedis arterinde gelişme geriliği ve/veya akım azlığı olduğu bilinmelidir. ${ }^{[27]}$ Literatürde, tibialis posterior arterinin gelişme geriliği olduğu olgular da mevcuttur. ${ }^{[28]}$

\section{TANI}

Ayağın görünüşü tipiktir. Topuk belirgin olarak ekindedir, ayak içe doğru dönüktür. Deformite pasif manipülasyon ile kolayca düzeltilebiliyorsa ve ayak mediyalposteriorunda belirgin cilt krizi yoksa, intrauterin dönemdeki duruş bozukluklarına bağlı pozisyonel DÇA olduğu düşünülür. Pozisyonel deformitelerde, bacakta atrofi veya ayak sertliği yoktur. Sendromlara bağlı oluşan DÇA'da ayak, idiyopatik olanlara göre daha serttir. İstisna sendromik hastalıklar, bağ gevşekliğinin eşlik ettiği Down ve Larsen sendromlarıdır. Bu sendromlara sahip hastalarda ayak şeklinde tama yakın düzelme beklenebilir. Artrogripozis, diastrofik displazi, Möbius sendromlarında düzeltme sağlamak zordur ve deformitenin tekrarlama olasılığı oldukça yüksektir. ${ }^{[1]}$ Tek taraflı olan olgularda, deforme ayak sağlam ayağa göre daha küçük ve atrofiktir.

Tüm hastalar nörolojik açıdan tam olarak değerlendirilmelidirler. DÇA'lı hastalarda radyolojik tanı konulması gerekliliği ile ilgili bir fikir birliği yoktur. Genel görüş, klinik değerlendirmenin yeterli olduğu yönündedir. ${ }^{[29]}$ Bu bölümde yine de, hastalığın radyolojik tanısı ile ilgili bilgi verilecektir. Gebe takibinde rutin olarak ultrasonografik değerlendirme yapılmasından ötürü, çoğu olgu intrauterin dönemde tanı alabilmektedir. İntrauterin 12. haftadan itibaren DÇA tanısı konulabilmekte ve gebelik haftası arttıkça deformite daha kolay tanınabilmektedir. ${ }^{[30]}$ Doğum sonrası ise, kemiklerin birbirleriyle olan 

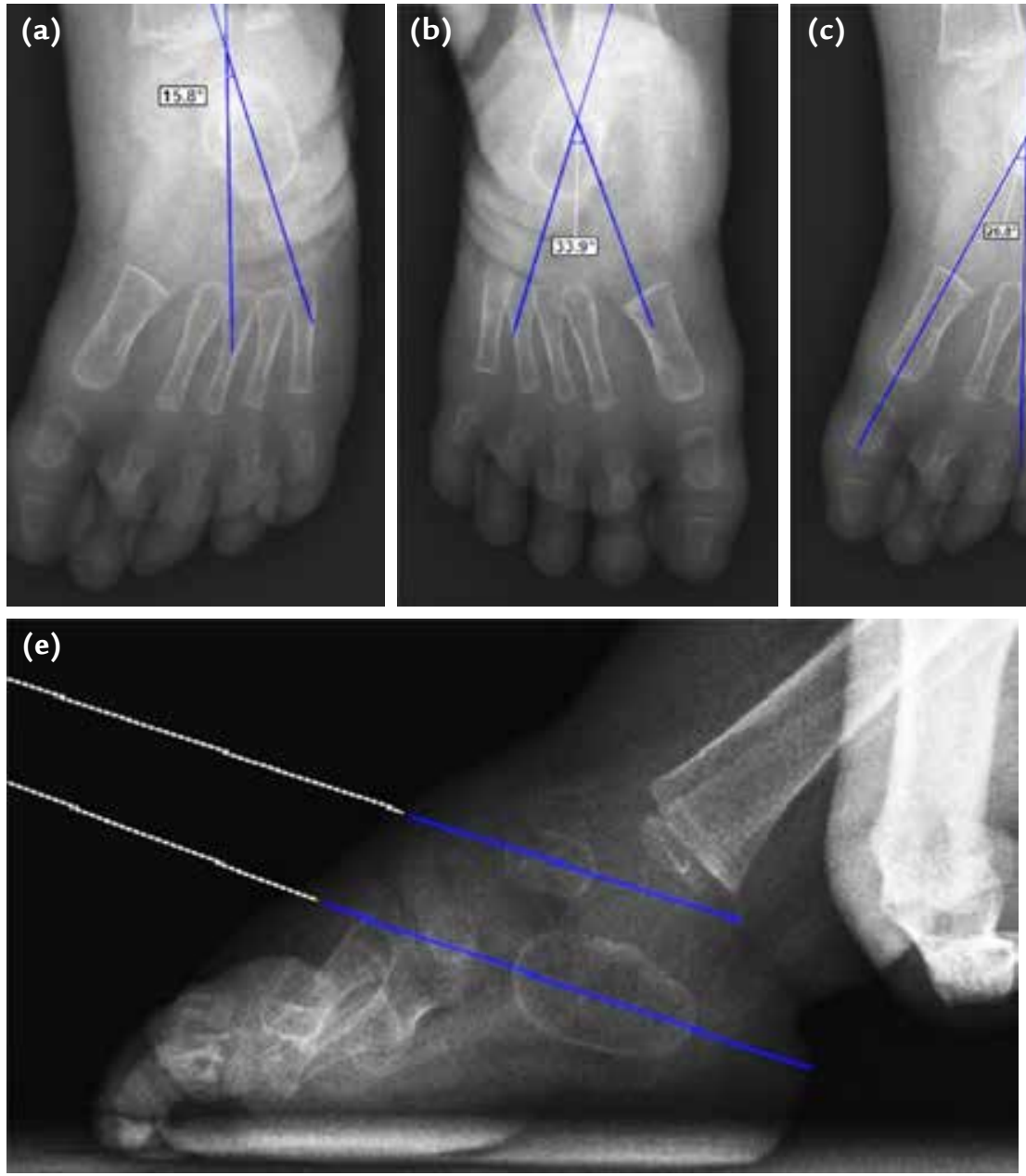
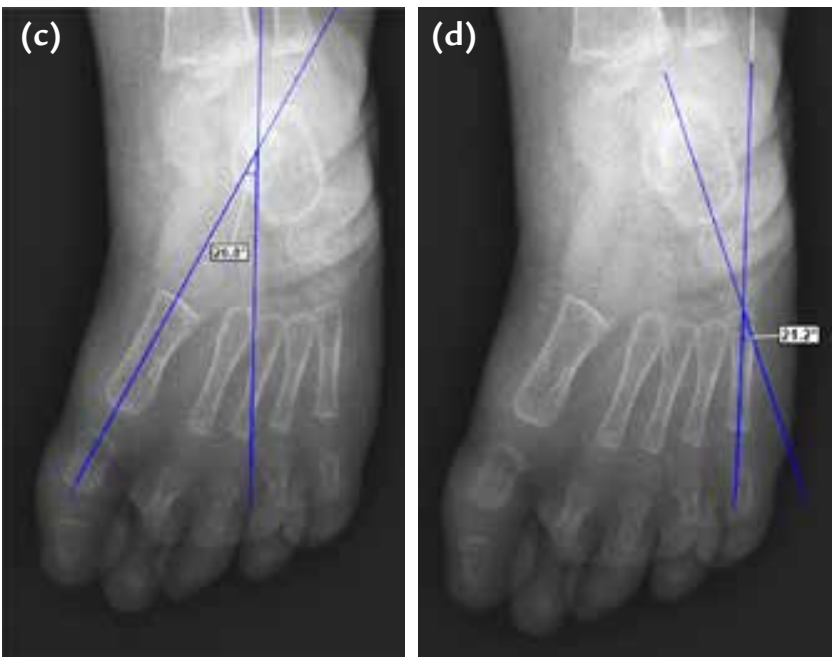

Şekil 1. a-e. Çarpık ayakta radyografik bulgular. ilişkilerinin değerlendirilmesinde direkt grafiler kullanılabilmektedir. Bilinmesi gereken; yeni doğmuş bir bebekte ayak kemiklerinden, kalkaneus, küboid, talus, metatarslar ve falanksların ossifiye oldukları ve küneiform kemikler ve navikulanın görülmedikleridir. Ön-arka grafi çekilirken ayak kasete bastırılmalı, yan grafi çekilirken de ayak dorsifleksiyona alınıp tam yan grafi elde etmek için bacak iç rotasyona çevrilmelidir. ${ }^{[29]}$

DÇA'lı hastaların ayak radyografilerinde görülen temel bulgu, her iki planda da talus ve kalkaneusun paralel hale gelmiş olmasıdır. Ön-arka grafilerde, talus ve kalkaneus kemikleşme merkezlerinin uzun akslarınca çizilen çizgiler arası açı değerinin $20^{\circ}$ altında olduğu görülür (Şekil 1b). Ön-arka grafide ölçülecek bir diğer parametre, talus ve 1. metatars uzun aksları arasında oluşan açıdır. Bu açının normal değeri $0^{\circ}$ ile $-20^{\circ}$ arasıdır; bu açı değerinin pozitifleşmesi (1. metatarsın, talus aksına göre mediyalizasyonu) anormal olarak kabul edilir (Şekil 1c). Ön-arka grafide kalkaneus ve 5. metatarsal kemiklerin uzun akslarının da birbirlerine yakın olmaları normal ayak radyografi bulgusudur; DÇA'lı hastalarda bu açı değeri de, 1. metatarsal kemik ve talus arasındaki açı değerine benzer olarak pozitifleşir (Şekil 1d). Yan radyografilerde ölçülen, talus ve kalkaneus uzun aksları arasında oluşan açıdır. Bu açı değeri normalde $35-55^{\circ}$ arasında olmalıdır. DÇA'lı hastalarda kalkaneus ve talus birbirlerine paralel hale geldiğinden, bu açı değeri de azalmış olarak ölçülür (Şekil 1e). ${ }^{[31]}$

Deformitenin ciddiyetinin değerlendirilmesi, hem prognostik açıdan hem de tedavinin gidişatını gözlemek açısından önemlidir. ${ }^{[1]}$ Aşağıda en sık kullanılan iki sınıflama sistemi anlatılacaktır.

\section{Pirani Skorlama Sistemi}

Pirani, deformitenin ciddiyetini; ayak arkasıyla ilgili üç, ayak ortasıyla ilgili üç olmak üzere toplam altı deformite parametresini baz alarak değerlendirmiştir (Tablo 1). ${ }^{[32]}$ Deformitenin ciddiyetine göre, her bir 
Tablo 1. Pirani skorlama sisteminde deformite tanımları

\begin{tabular}{l}
\hline Ayak arkası deformiteleri \\
- Posterior topuk krizi \\
- Topuktaki boşluk \\
- Ekinus rijiditesi \\
\hline Ayak ortası deformiteleri \\
- Ayak lateral kenarının kavislenmesi \\
- Mediyal kriz \\
- Talus başının kapsanmaması \\
Toplam skor = [Ayak arkası + ayak ortası] deformite skoru
\end{tabular}

parametre; deformite rijitse 1 puan, hafifse 0,5 puan ve yoksa 0 puan alır. Toplamda elde edilen değer 6 ise "ciddi DÇA", 0 ise "normal ayak" olarak ifade edilir. ${ }^{[33]}$

\section{Dimeglio Skorlama Sistemi}

Dimeglio sistemi ${ }^{[34]}$, dört farklı parametrenin değerlendirmesine dayanan ayrıntılı bir skorlama sistemidir. Bu parametreler: 1) sagittal plandaki ekinus, 2) frontal plandaki varus sapması, 3 ) horizontal planda kalkaneo-pedal bloğun derotasyonu, 4) horizontal planda ön ayağın arka ayağa göre adduksiyonudur (Şekil 2). Her parametreye, ilgili planda redükte edilebilirliğine (a)
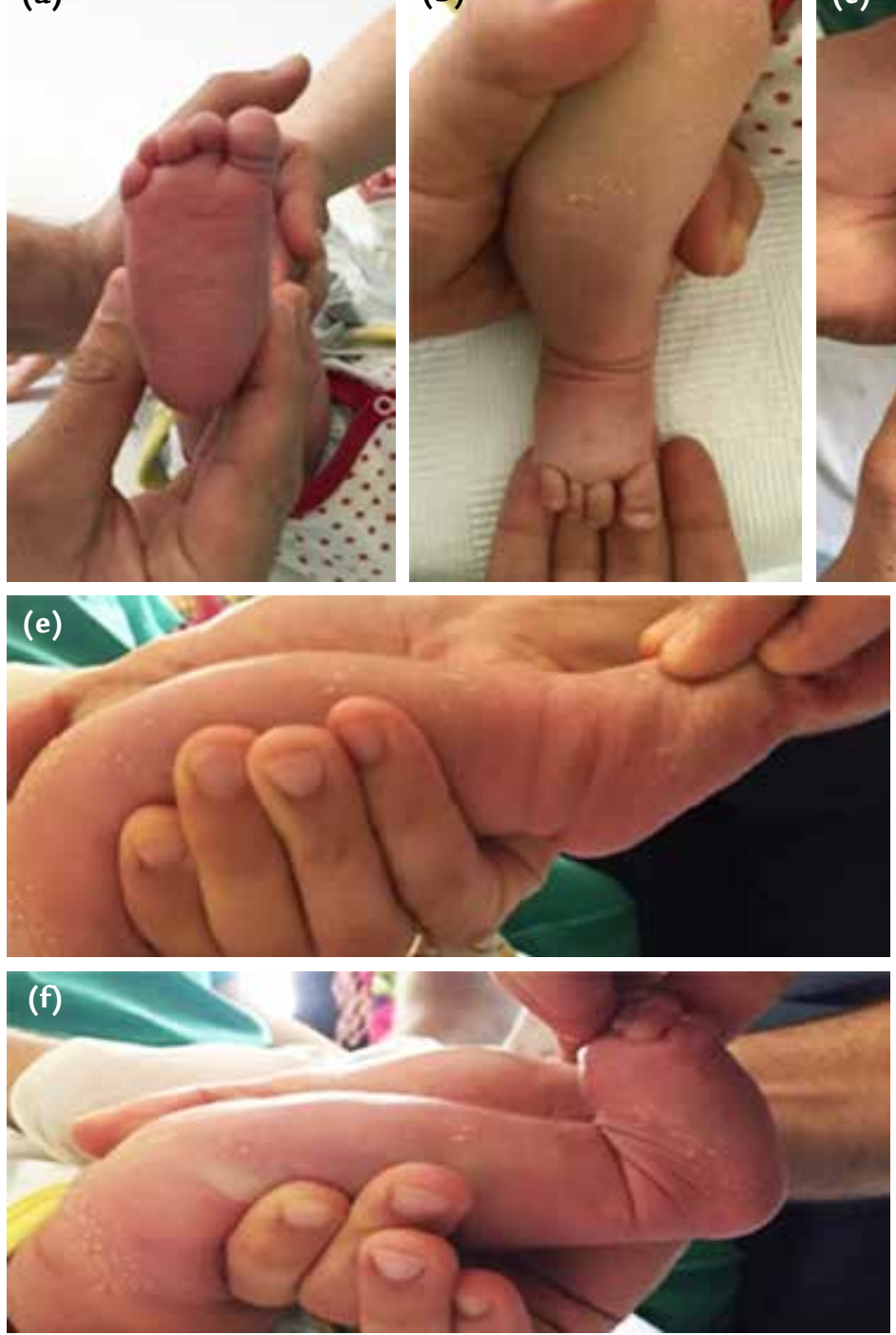

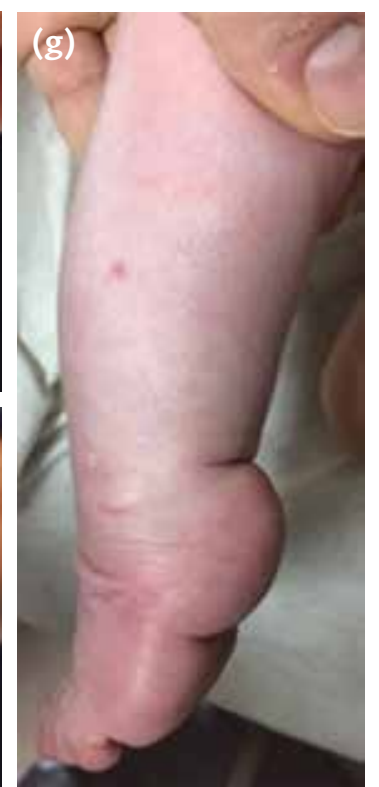

\section{(c)}
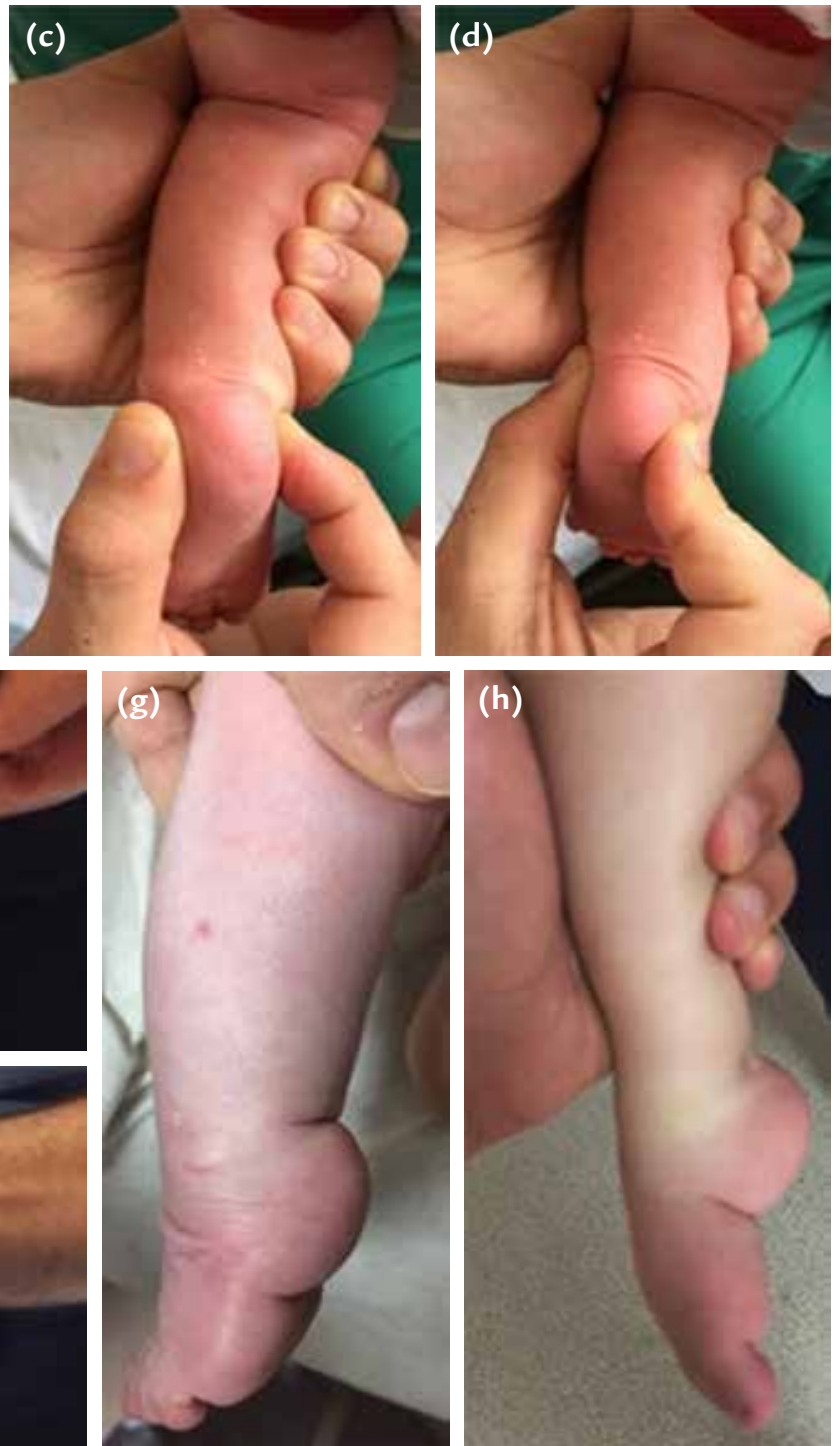

Şekil 2: a-h. Horizontal planda ön ayak varusunun değerlendirilmesi (a). Horizontal planda kalkaneopedal bloğun değerlendirilmesi (b). Frontal planda varus değerlendirilmesi (c, d). Sagittal planda ekinusun değerlendirilmesi (e, f). Posterior ve mediyal krizler (g). Kavus (h). 
göre 0'dan 4'e kadar puan verilir (Tablo 2). Bunlara ek olarak; mediyal kriz, posterior kriz, kavus ve baldır kas yapısında zayıflık olması birer puan alarak değerlendirmeye dahil edilir. ${ }^{[35]}$ En yüksek skor 20'dir (Tablo 3). Skor yükseldikçe deformitenin ağırlığı artar. Deformite, aldığı toplam puana göre; hafif, orta, ağır ve çok ağır olarak derecelenir. ${ }^{[36]}$

\section{CERRAHI DIŞI TEDAVi}

Günümüzde hemen hemen tüm ortopedi hekimleri tarafından kabul edilen görüş, idiyopatik çarpık ayağın başlangıç tedavisinin cerrahi dışı tedavi olduğudur. Yine, çoğunluk tarafından kabul edilen diğer bir görüş ise, tedaviye ne kadar erken başlanırsa o kadar yararIı olacağı yönündedir. Cerrahi dışı tedaviyi savunma felsefesi, bunun nihai bir tedavi yöntemi olacağı görüşünü benimseyerek, daha sonra gerekebilecek cerrahi müdahale gereksinimini ortadan kaldırmaya ya da en aza indirmeye çabalamaktan geçmektedir. Tedavideki esas amaç, yere düzgün basan, ağrısız ve fonksiyonel bir ayak elde etmektir. Tedavinin iki komponenti vardır. Illki deformiteyi düzeltmek, ikincisi ise ayağın bu düzeltilmiş pozisyonunu koruyarak nüksü engellemektir. Ebeveynlerin tedaviye uyumu nüks gelişiminin önlenmesinde önemli rol oynamaktadır. İdiyopatik çarpık ayak deformitesi tedavisinde kullanılan Ponseti yöntemi ve Fransız fizyoterapi yöntemi, cerrahiye olan gereksinimi azaltmada başarılı olmuşlardır. Her iki metodla da, başlangıçtaki çarpık ayak deformitesi \%95 oranında düzeltilebilmektedir. ${ }^{[37]}$

Tablo 2. Dimeglio'ya göre deformite derecelendirilmesi ${ }^{[34]}$

\begin{tabular}{lc}
\hline Redükte edilebilirlik & Puan \\
\hline $90^{\circ}$ ile $45^{\circ}$ arası & 4 \\
$45^{\circ}$ ile $20^{\circ}$ arası & 3 \\
$20^{\circ}$ ile $0^{\circ}$ arası & 2 \\
$0^{\circ}$ ile- $20^{\circ}$ arası & 1
\end{tabular}

\section{Ponseti Yöntemi}

Ignacio Ponseti, 1940'ların sonuna doğru çarpık ayak deformitesi için kendi tedavi yöntemini geliş̧irmiştir. ${ }^{[38]}$ Bu yöntem, çarpık ayak tedavisinde kullanılan ekstensil cerrahi yöntemler sonrasında, zaman içinde rezidüel deformiteli ve ağrılı ayakların ortaya çıktığı gözleminden yola çıkılarak geliştirilmiştir. Ponseti, çarpık ayak tedavisinde daha az invaziv ve daha efektif bir tedavi yöntemi olması gerektiğine inanarak, hastalığın fonksiyonel ve patolojik anatomisini daha iyi anlamak için yoğun çalışmalar yapmış ve sonucunda çarpık ayak tedavisinde Ponseti Yöntemi'ni ortaya koymuştur. ${ }^{[39]}$

\section{$T_{e k n i k}^{[38,39]}$}

Ponseti yöntemi, ayağın seri manipülasyonlarını takip eden alçılama ile deformitenin kademeli olarak düzeltilmesi esasına dayanır. Düzeltilmesi gereken ana deformiteler; ayak ortası kavusu, ayak önü adduksiyonu, ayak arkası varusu ve ekinusudur. Bu deformiteler, başarılı bir tedavi sonucu için sıralandıkları şekilde düzeltilmelidir. Her seansta ayak 1-3 dakika süreyle, sırasıyla bu deformiteleri düzeltecek şekilde manipüle edilir. Daha sonra elde edilen düzeltme, diz $90^{\circ}$ fleksiyonda dizüstü alçı yapılarak bir sonraki seansa kadar korunur. Seans araları 5-7 gün arasında değişmektedir. Alçı uygulamaları esnasında çocuğun biberonla beslenmesi önerilir. Çünkü bu durum çocuğun dikkatini dağıtarak alçı yapımını kolaylaştırabilir. Rezidüel ekinusun düzeltimesi için Aşil tenotomisi çoğu olguda gerekmektedir. ${ }^{[39]}$

Tedavinin ilk amacı kavusun düzeltilmesidir; bu da, birinci metatarsın elevasyonu ve ön ayağın arka ayağa göre supinasyona alınmasıyla sağlanır. Kavus bu manevrayla neredeyse her zaman ilk alçıyla düzelir. ${ }^{[40]}$ Kavus düzeltilirken dikkat edilmesi gereken önemli bir nokta, ayağın asla pronasyona getirilmemesi gerektiğidir. Ayak kavusu düzeltilmeden diğer düzeltme basamağına geçilmemelidir.

Takip eden seanslarda, talus başının lateraline baskı uygulayarak ayağı kademeli olarak abduksiyona almak,

Tablo 3. Dimeglio'ya göre doğuştan çarpık ayak deformitesinin ağırlı̆̆ının derecelendirilmesi

\begin{tabular}{cccl}
\hline $\begin{array}{c}\text { Sınıflama } \\
\text { derecesi }\end{array}$ & Tip & Toplam Skor & Redükte edilebilirlik \\
\hline I & Hafif & $<5$ & Yumuşak-yumuşak, düzeltilebilir \\
II & Orta & 5 ile $<10$ arası & Yumuşak-sert, düzeltilebilir, kısmen dirençli \\
III & Ağır & 10 ile $<15$ arası & Sert-yumuşak, dirençli, kısmen düzeltilebilir \\
IV & Çok ağır & 15 ile $<20$ arası & Sert-sert, dirençli
\end{tabular}


ayak önü adduksiyonunda ve ayak arkası varusunda eş zamanlı olarak düzeltme sağlar. Talusun ayak bileği mortisi içinde sabitlenmesiyle birlikte uygulanan abduksiyon, kalkaneusun talusun altından abduksiyon, eversiyon ve dorsifleksiyon yapmasına izin vererek ayak arkası varusunda düzelmeye olanak verir. Bu nedenle manipülasyonlar esnasında talus başı laterali dışındaki noktalara uygulanan karşı kuwet kalkaneusun talus altındaki serbest salınımını engelleyerek ayak arkası varusunun ve kalkaneal inversiyonun düzelmesine engel olur. Subtalar eklem deformitesi tamamen düzelmeden ve/veya Aşil tenotomisi uygulanana kadar ayağa aktif dorsifleksiyon uygulanmamalıdır; çünkü bu zorlu manipülasyon ayakta rocker-bottom deformitesine yol açabilir.[1] Genellikle haftada bir yapılan üç ya da dört alçılamadan sonra, tarsal kemiklerin mediyal ligamentöz yapılarında gevşeme ve eklemlerde parsiyel olarak redüksiyon gerçekleşir. Her alçı değişiminde, tarsal kemiklerin inversiyonunu düzeltmek üzere ayak supinasyonu kademeli olarak azaltılırken ayak abduksiyonu arttırılır. Talustan karşı güç uygulanırken ayak bacağa göre $70^{\circ}$ 'ye kadar abduksiyona getirilmelidir. Bu abduksiyon derecesi aşırı görünebilir; ancak, sadece bu manevra subtalar eklemde tam düzelme ve mediyal yapılarda yeterli esneme sağlar. ${ }^{[41]}$

Ekinus en son düzeltilen deformitedir. Ayak arkası nötral ya da hafif valgus duruşunda olduğunda düzeltmeye başlanabilir. Progresif olarak esnetme ve dorsifleksiyon arttırılarak alçılamayla düzeltilebileceği gibi, olguların yaklaşık \%85'inde rezidüel ekinusun düzeltilmesi için Aşil tenotomisi ihtiyacı görülmektedir. ${ }^{[42]}$ Tenotomi, poliklinik şartlarında lokal anesteziyle ya da ameliyathanede genel anestezi altında son alçı uygulamasından önce yapılır ve ardından, maksimum dorsifleksiyonda ve $70^{\circ}$ 'ye kadar abduksiyonda, kasıktan parmak ucuna kadar uzun bacak alçı yapılır. Perkütan Aşil tenotomisiyle daha hızlı düzeltme sağlanır. Bir yaşına kadar olan çocuklarda yapıldığında, aşırı uzatma ya da baldır kaslarında güçsüzlük ortaya çıkarmaz. Son dönemde literatürde mini-açık Aşil tenotomisini de savunan görüşler mevcuttur. MacNeille ve ark. ${ }^{[43]}$ yaptıkları bir geriye dönük çalışmada, ameliyathanede kısa süreli genel anestezi altında uygulamakta oldukları mini-açık Aşil tenotomi yönteminin etkili ve güvenilir olduğunu göstermişlerdir. Mini-açık teknikle yapılan Aşil tenotomisinde nörovasküler yaralanma ve inkomplet tenotomi riskinin en aza indiğini bildirmişlerdir. Son alçı 3-4 hafta sonra çıkarılarak, bar ve ayakkabı şeklindeki ayak abduksiyon ortezi (Dennis Browne ortezi) kullanımına başlanır. Ayakkabılar bar üstünde omuz genişliğinde sabitlenmeli, iki taraflı olgularda her iki ayak $70^{\circ}$ dış rotasyon ve $5-10^{\circ}$ dorsifleksiyonda olmalıdır. Tek taraflı olgularda, etkilenmeyen ayak $40^{\circ}$ dış rotasyonda tutulmalıdır. Ortez 3-4 ay boyunca tüm zamanlı olarak ve takip eden dönemde 2-4 yıl boyunca uyku esnasında kullanıımalıdır.

\section{Fransız Fizyoterapi Yöntemi}

Fransız yöntemi, bu konuda eğitimli bir fizyoterapist tarafından, günlük olarak yenidoğan çocuğun çarpık ayağına yapılan manipülasyonlarla deformitenin redüksiyonu, ayak çevresi kasların özellikle de peroneal kasların stimülasyonu ve redüksiyonu korumak amacıyla ayağın geçici olarak elastik ve elastik olmayan yapışkan bantlarla bantlanmasını içerir. Düzelmenin çoğu ilk üç ay içinde elde edilir; beşinci ayda tam düzelme beklenir. ${ }^{[44]}$ Bu teknik ebeveynlere öğretilerek, germe, bantlama ve atelleme programına evde günlük olarak devam edilmesi sağlanır. Başarılı olunduysa; bu program, çocuk yürüme çağına (2-3 yaş) gelene kadar devam ettirilir. Bu süreden sonra sonuç genellikle dengelendiğinden dolayı, tedavi sonlandırılır. ${ }^{[45]}$ Ergenlik çağına kadar düzenli kontrollere devam edilir.

\section{CERRAHI TEDAVI}

Konservatif tedaviye dirençli bir deformitede son çare cerrahi düzeltmedir. Dirençli ya da nükseden bir çarpık ayak deformitesinde plantigrad bir ayak elde etmek için cerrahi tedavi gerekmektedir. Cerrahi gevşetme tüm patoanatomik yapılara uygulanmalıdır. Çoklu operasyonlardan kaçınmak gerekir; çünkü, tekrarlayan operasyonlar sonrası ayakta sertleşme, skar dokusunda derinleşme ve immobilizasyona bağlı atrofi yaygındır. ilk ameliyatı gerçekleştiren cerrahın deformiteyi tamamen düzeltme şansı en yüksektir; bu nedenle cerrahi planlamayı ve zamanlamayı belirleme konusunda sorumluluğu artmaktadır. ${ }^{[46]}$

\section{Cerrahi Zamanlama}

Konservatif tedavinin başarısız olacağı öngörülen infantlarda cerrahi tedavi, 12 aylıktan yani çocuk yürümeye hazır duruma gelmeden önce yapılmalıdır. Dimeglio ve Pous, her ne kadar önceleri 1-6 haftalık bebeklerde cerrahi gevşetmeler yapmış olsalar da, artmış skar dokusu ve tekrarlayıcı fibrozis nedeni ile bu uygulamalarından vazgeçmişlerdir. ${ }^{[4]}$ Turco ise, hem dokulara hakimiyet hem de onarılan dokuların doğru pozisyonda yeterince tespit edilebilmeleri açısından, cerrahi tedavinin bir yaş ve sonrasında uygulanmasını önermiştir. ${ }^{[48]}$ Günümüzde deneyimli bir cerrah tarafından beş aylık gibi erken bir yaşta bile cerrahi tedavi uygulanabileceği öne sürülse de, bu kadar erken cerrahi uygulanan hastaların, yürüyene kadar nüksü önlemek için cihaz kullanmaları zorunludur. Tüm bu nedenlerden dolayı, cerrahi için en uygun zaman 9-10 ay arasıdır. ${ }^{[6]}$ 


\section{Yumuşak Doku Ameliyatları}

İdiyopatik çarpık ayakta tam anatomik düzeltmenin başarılabilmesi için tanımlanmış birden fazla cerrahi teknik mevcuttur. Bu tekniklerden ilki, 1971 yılında Turco tarafından ortaya atılmıştır. Turco, hasta supin pozisyonda yatarken eğri posteromediyal insizyon kullanarak, subtalar bölgede lateral, posterior, mediyal gevşetmeler yaparak, tam subtalar düzeltmeyi hedefler ve gevşetmelerine kalkaneofibular bağı da ekler. Turco'nun tanımladığı yöntem, daha sonraları ihtiyaçlar doğrultusunda, onun adına modifiye edilmiştir. ${ }^{[46]}$ Carroll, ön ayak adduksiyon ve supinasyonunun (kavus) Turco'nun tanımladığı yöntem ile giderilemediğine dikkat çekerek, abduktor hallusis kası, plantar fasya ve kalkaneoküboid eklemin de gevşetilmesi gerektiğini vurgulamıştır. ${ }^{[49]}$ Talusun rotasyonunun deformitenin oluşumunda birincil sorumlu olduğuna inanan Goldner, buna derin mediyal deltoid bağların da gevşetilmesini ve sonra gerekli olursa onarılmasını içeren subtalar gevşetme ve sinus tarsiye uyan lateral insizyonla kalkaneoküboid kapsülotomi eklemiş ve aynı insizyondan lateral talonaviküler kapsülorafi uygulanmasını da önermiştir. ${ }^{[50]}$ Daha geniş kapsamlı girişimler, McKay ve Simons tarafından Cincinnati insizyonu kullanılarak tüm talus çevresi, ayak arka ve orta eklemlerinin gevşetilmesi şeklinde uygulanmıştır. ${ }^{[51,52]}$ Tüm bu girişimlerde mutlaka Aşil tendonunun uzatılması önerilmektedir.

Kliniğimizde, DÇA'lı bebeklere en erken dönemde konservatif tedaviye başlanmaktadır. Konservatif tedavide, Ponseti tarafından tanımlanan yöntem uygulanmaktadır. Ortalama 6-8 alçılama sonrası, Aşil tendon uzatması, posterior tibiotalar ve subtalar eklem kapsülotomileri ve kalkaneofibular bağ gevşetilmesi yapılmaktadır. ${ }^{[6]}$ Hastaların erken dönem sonuçları genellikle başarılı olmaktadır. Tedaviye dirençli ve artrogripotik ayaklarda, nörolojik hastalığa ikincil deformitesi olan, nüks gelişen ve ihmal edilmiş hastalarda, kısmi hatta bazen tam subtalar gevşetmeye ihtiyaç duyulabilmektedir.

Hastaya, genel anestezi ve/veya kaudal epidural anestezi sonrası, supin pozisyonda ameliyat uygulanır. Steril Esmarch bandajı ile alt ekstremite venöz kanı boşaltıldıktan sonra, kesi uygulanır. Cerrahi kesi, düzeltilmesi gerekli olan deformiteye göre; posteromediyal, posteromediyal-lateral veya Cincinnati insizyonu şeklinde yapılabilir. Önemli olan, kesi altındaki tüm deformitelerin görülebilmesi ve düzeltilebilmesidir. Cerrahların çoğu, kozmetik olarak avantajlı olduğu, geniş görüş sağladığı ve güvenli olduğu için, Cincinnati insizyonunu tercih etmektedir. Bu insizyonda topuk dolaşımının korunması için, kesi posterior krizin en az $1 \mathrm{~cm}$ üzerinden yapılmalıdır. ${ }^{[53,54]}$ illk olarak Aşil, Z plasti şeklinde uzatılır.
Posterior tibiotalar ve subtalar kapsüller, kalkaneofibular bağ kesilir. Kavus, adduktus ve varus varlığında, plantar fasya kesilir ve abduktor hallusis kası kalkaneusa yapışma yerinden gevşetilir. Eğer talonaviküler eklem redükte değil ise, tibialis posterior tendon $Z$ şeklinde uzatılır. Bu uzatmaya rağmen halen redüksiyon sağlanamadıysa, talonaviküler kapsül mediyalden başlanarak plantar ve dorsale doğru gevşetilir. Navikulanın alt kısmında bulunan Y (spring-plantar kalkaneo-naviküler) bağının gevşetilmesi oldukça önemlidir. Talonaviküler eklemin çok fazla gevşetilmesi instabiliteye neden olabileceğinden, dikkatli davranılmalıdır. Henry düğümü, fleksör tendonları bulmak açısından önemlidir. Dügüüm bulunur ve gevşetilir. Fleksör hallusis longus ve fleksör dijitorum longus tendonları, mediyal damar-sinir paketi askıya alındıktan sonra uzatılmalıdır. Yapışıklığın önlenebilmesi açısından, bu uzatma işlemleri ayak ortasında yapılmamalıdır. İnterosseöz bağ, çok yönlü rotasyonun menteşe noktası olduğundan dolayı korunur; fakat, CSTR (Complete Subtalar Release)'nin orijinalinde kesilmesi önerilmektedir. ${ }^{[46]}$ Deltoid bağın derin kısmı mutlaka korunmalıdır. Ardından, uzatılan dört tendon (FHL, FDC, Aşil ve tibialis posterior) uygun gerginlikte onarılır. Posteromediyal gevşetmeler tamamlandıktan sonra ayak önü nötralden abduksiyona getirilerek (eğer abduksiyon sağlanamıyorsa) lateral gevşetme gerekip gerekmediğine karar verilir. Ayak önü nötralden öteye abduksiyona getirilemiyorsa, ayrıca lateral subtalar kapsül ve kalkaneoküboid eklem kapsülü de gevşetilmelidir. ${ }^{[55]}$ Gevşetmeler sonrası talustan naviküler ve kalkaneustan talusa giden birer adet Kirscher teli (K-teli) gönderilir. Kanama kontrolünü takiben, katlar kapatılır. Kapatma esnasında topuğun arka bölgesinde ciltte gerginlik varsa, yara iyileşene kadar ayak ekin pozisyonunda alçılanır ve tedrici olarak ekini azaltacak alçılamalaryapılır. Alçı ve K-telleri 6-8 hafta sonrasında çıkarılır. Ardından germe egzersizleri uygulanır ve AFO (Ankle-Foot-Orthosis) cihazı verilir. Cihaz, 3-6 ay arası uygulanır. Ancak, iyi bir cerrahi tedavi sonrası nüksü engelleyen en önemli şey, cihazdan çok egzersizdir. Kimi cerrahlar 6-7 yaşlara kadar çeşitli ayakkabılar önerse de, günlük pratikte bunlar çok kullanılmamaktadır. ${ }^{[46]}$

\section{Revizyon ve İkincil Ameliyatlar}

İnfantlık döneminde, başlangıçtaki yumuşak doku gevşetmesi sonrası tekrarlayan cerrahi sıklığının \%10'lar civarında olduğu tahmin edilmektedir. ${ }^{[1]}$ Revizyon cerrahisini seçerken, tekrarlayan cerrahilerin ve takip eden immobilizasyonun yarattığı olumsuzluklar göz önünde bulundurularak, mümkün olan en az sayıda prosedürle gerçekçi nihai ayak pozisyonu elde edilmeye çalışılmalıdır. Bu yüzden, örneğin, üç yaşında tekrar eden deformitenin hemen düzeltilmesi yerine, 
önemli ölçüde yumuşak doku disseksiyonu ve immobilizasyon yapmaksızın kemik ameliyatlarıyla nihai sonucun elde edilebileceği 10 yaşına kadar cerrahi müdahale geciktirilebilir. ${ }^{[1]}$

\section{Anterior Tibial Tendon Transferi}

Ayak ortasının dinamik inversiyon ya da supinasyon deformitesi varlı̆̆ında, anterior tibial tendonun parsiyel ya da total transferi endikasyonu ortaya çıkar. Parsiyel transfer yapılacaksa, tendonun laterali alınarak tibia distal ucundaki ekstansör retinakulum altından geçirilerek küboide ya da lateral küneiform kemiğe tespiti sağlanır. Lateral kısmın gerginliği, statik olarak ayağı hafif eversiyon ve pronasyonda tutacak şekilde ayarlanmalıdır. Tendonun tamamı transfer edilecekse, ayağın dorsifleksiyonu esnasında aşırı abduksiyona gitmesini engellemek için, insersiyo orta hatta ya da orta hattın hafif lateraline (üçüncü küneiform) taşınmalıdır. ${ }^{[1]}$

\section{Lateral Kolon Kısaltma}

Tekrarlayan çarpık ayak deformitesinde genellikle tüm dört komponent de bulunur; ancak, esas sorun ayağın lateral kenarının mediyal kenarına göre daha uzun olmasından ortaya çıkıyor olabilir. Ayağın supinasyonu ve abduksiyonuna engel olan, kontrakte mediyal yapılar ve lateral kolonun aşırı uzun olmasıdır.

Evans, 1961 yılında nüks çarpık ayağın posteromediyal gevşetmeyle birlikte kalkaneoküboid eklemin kama rezeksiyonu ve füzyonu ile tedavisini tanımlamıştır. ${ }^{[56]}$ Evans prosedürü, orta ayağın talonaviküler ve kalkaneoküboid eklemin mediyal deplasmanı sonucu aşikar varusta olduğu nüks çarpık ayak deformitesinde standart tedavi haline gelmiştir. Aynı zamanda, geç tanı konmuş ilerlemiş çarpık ayak deformitesinde de ideal bir başlangıç prosedürüdür. Alternatif olarak, lateral kolon kısaltmasının kalkaneusun anterior kısımından veya eklemin proksimalindeki kalkaneus boynundan ya da küboidden yapıldığı yöntemler tanımlamıştır. ${ }^{[1]}$

\section{Kalkaneal Osteotomi}

Sabit topuk varusu deformiteli bir ayakta kalkaneusun, açık ya da kapalı kama ya da laterale kaydırma osteotomisi izole bir prosedür olarak nadiren kullanılmaktadır. ${ }^{[1]}$

\section{Supramalleolar Ostetotomi}

Tedavi sonrası, elde edilen plantigrad ayaklarda uygulanan cerrahi yöntemlerden bağımsız olarak içe basmanın devam etmesi yaygındır. İçe basmanın ciddi olduğu ve iki senelik takibin sonunda düzelme gözlenmemesi durumunda, supramalleolar dış rotasyon osteotomisi yararlı olabilir. ${ }^{[1]}$

\section{Üçlü Artrodez}

On yaşından sonra rezidüel defromitelerin düzeltilmesi, ancak kemiksel düzeltme ve tespit ile mümkün olmaktadır. Semptomatik, tekrarlayıcı deformiteli büyük çocuklarda en son kurtarıcı prosedür olarak üçlü artrodez kullanılabilir. ${ }^{[1]}$

\section{Talektomi}

Talektomi miyelomeningosel ve artrogripozis multipleks konjenitaya ikincil görülen çarpık ayak tedavisinde primer ve rekürrensler sonrası salvaj prosedürü olarak kullanılabilmektedir. ${ }^{[57]}$

\section{KAYNAKLAR}

1. Ricco Al, Richards BS, Herring JA, Disorders of the Foot. In: Herring JA, editor. Tachdjian's Pediatric Orthopaedics. Philadelphia PA: Saunders; 2013. p.761-883.

2. Shimode K, Miyagi N, Majima T, Yasuda K, Minami A. Limb length and girth discrepancy of unilateral congenital clubfeet, J Pediatr Orthop B 2005;14(4):280-4.

3. Spiegel DA, Loder RT. Leg-length discrepancy and bone age in unilateral idiopathic talipes equinovarus, J Pediatr Orthop 2003:23(2):246-50.

4. Ošt'ádal M, Lišková J, Hadraba D, Eckhardt A. Possible Pathogenetic Mechanisms and New Therapeutic Approaches of Pes Equinovarus. Physiological Research 2017;66(3):403-10.

5. Wynne-Davies R. Family studies and the cause of congenital club foot. Talipes equinovarus, talipes calcaneo-valgus and metatarsus varus. J Bone Joint Surg Br 1964;46(3):445-63.

6. BernhardtDB. Prenatal and postnatal growth and development of the foot and ankle. Phys Ther 1988;68(12):1831-9.

7. Balasankar G, Luximon A, Al-Jumaily A. Current conservative management and classification of club foot: A review. J Pediatr Rehabil Med 2016;9(4):257-64. Crossref

8. Ošt'ádal $M$, Chomiak J, Dungl $P$, Frydrychová $M$, Burian $M$. Comparison of the short-term and long-term results of the Ponseti method in the treatment of idiopathic pes equinovarus. Int Orthop 2013;37(9):1821-5. Crossref

9. Bonnell J, Cruess RL. Anomalous insertion of the soleus muscle as a cause of foxed equinus deformity. A case report. J Bone Joint Surg Am 1969:51(5):999-1000.

10. Gurnett CA, Alaee F, Kruse LM, Desruisseau DM, Hecht IT, Wise CA, Bowcock AM, Dobbs MB. Asymmetric lower-limb malformations in individuals with homeobox PITX1 gene mutation. Am J Hum Genet 2008;83(5):616-22. Crossref

11. Böhm M. The embryologic origins of clubfoot. J Bone Joint Surg 1929:11(2):229-59.

12. Zimny ML, Willig SJ, Roberts JM, D'Ambrosia RD. An electron microscopic study of the fascia from the medial and lateral sides of clubfoot. J Pediatr Orthop 1985;5(5):577-81.

13. Li C, Nguyen Q, Cole WG, Alman BA. Potential treatment for clubfeet based on growth factor blockade. J Pediatr Orthop 2001;21(3):372-7.

14. Ahmed M, Ahmed N, Khan KM, Umer M, Rashid H, Hashmi $\mathrm{P}$, Umar M. Sensory hypoinnervation in club foot. J Bone Joint Surg Br 2004;86(8):1163-9.

15. Irani RN, Sherman MS. The pathological anatomy of idiopathic clubfoot. Clin Orthop Relat Res 1972;84:14-20. 
16. Lubicky JP, Altiok H. Regional fasciocutaneous flap closure for clubfoot surgery. J Pediatr Orthop 2001;21(1):50-4.

17. Handelsman JE, Badalamente MA. Neuromuscular studies in clubfoot. J Pediatr Orthop 1981;1(1):23-32.

18. Paton RW, Freemont AJ. A clinicopathological study of idiopathic CTEV. J R Coll Surg Edinb 1993;38(2):108-9.

19. Herceg MB, Weiner DS, Agamanolis DP, Hawk D. Histologic and histochemical analysis of muscle specimens in idiopathic talipes equinovarus. J Pediatr Orthop 2006;26(1):91-3. Crossref

20. Lochmiller C, Johnston D, Scott A, Risman M, Hecht JT. Genetic epidemiology study of idiopathic talipes equinovarus. Am J Med Genet 1998;79(2):90-6.

21. Pirani S, Zeznik L, Hodges D. Magnetic resonance imaging study of the congenital clubfoot treated with the Ponseti method. J Pediatr Orthop 2001;21(6):719-26.

22. Howard CB, Benson MK. Clubfoot: its pathological anatomy. J Pediatr Orthop 1993;13(5):654-9.

23. Downey DJ, Drennan JC, Garcia JF. Magnetic resonance image findings in congenital talipes equinovarus. J Pediatr Orthop 1992;12(2):224-8.

24. Epeldegui T, Delgado E. Acetabulum pedis. Part II: Talocalcaneonavicular joint socket in clubfoot. J Pediatr Orthop B 1995;4(1):11-6.

25. Ippolito E. Update on pathologic anatomy of clubfoot. J Pediatr Orthop B 1995;4(1):17-24.

26. Simons GW. Calcaneocuboid joint deformity in talipes equinovarus: an overview and update. J Pediatr Orthop B 1995;4(1):25-35

27. Katz DA, Albanese EL, Levinsohn EM, Hootnick DR, Packard DS Jr, Grant WD, Mann KA, Albanese SA. Pulsed color-flow Doppler analysis of arterial deficiency in idiopathic clubfoot. J Pediatr Orthop 2003;23(1):84-7.

28. Dobbs MB, Gordon JE, Schoenecker PL. Absent posterior tibial artery associated with idiopathic clubfoot. A report of two cases. J Bone Joint Surg Am 2004;86-A(3):599-602.

29. Vincent SM. The foot, In: Weinstein SL, Flynn JM, editors. Lovell and Winter's Pediatric Orthopaedics, Level 1 and 2, 7th ed. Philadelphia: Lippincott, Williams \& Wilkins; 2014. p.1388-525

30. Keret D, Ezra E, Lokiec F, Hayek S, Segev E, Wientroub S. Efficacy of prenatal ultrasonography in confirmed club foot. J Bone Joint Surg Br 2002;84(7):1015-9.

31. Simons GW. Analytical radiography of club feet. J Bone Joint Surg Br 1977;59-B(4):485-9.

32. Pirani S. A method of assessing the virgin clubfoot. Orlando, FL.: Pediatric Orthopaedic Society of North America (POSNA); 1995.

33. Docker CEJ, Lewthwaite S, Kiely NT. Ponseti treatment in the management of clubfoot deformity - a continuing role for paediatric orthopaedic services in secondary care centres. Ann R Coll Surg Engl 2007;89:510-2. Crossref

34. Diméglio $A$, Bensahel $H$, Souchet $P$, Mazeau $P$, Bonnet F. Classification of clubfoot. J Pediatr Orthop B 1995:4(2);129-36.

35. Wainwright AM, Auld T, Benson MK, Theologis TN. The classification of congenital talipes equinovarus. J Bone Joint Surg $\operatorname{Br} 2002 ; 84(7): 1020-4$.

36. Lampasi M, Trisolino G, Abati CN, Bosco A, Marchesini Reggiani L, Racano C, Stilli S. Evolution of clubfoot deformity and muscle abnormality in the Ponseti method: evaluation with the Dimeglio score. Int Orthop 2016;40(10):2199-205. Crossref
37. Steinman S, Richards BS, Faulks S, Kaipus K. A comparison of two nonoperative methods of idiopathic clubfoot correction: the Ponseti method and the French functional (physiotherapy) method. Surgical technique. J Bone Joint Surg Am 2009;91 Suppl 2:299-312. Crossref

38. Ponseti IV. Congenital Clubfoot: Fundamentals of Treatment. New York: Oxford University Press; 1996.

39. Dobbs MB, Gurnett CA. Update on clubfoot - etiology and treatment. Clin Orthop Relat Res 2009;467(5):1146-53. Crossref

40. Frick SL. The Ponseti method of treatment for congenital club-foot: importance of maximal forefoot supination in initial casting. Orthopedics 2005;28(1):63-5.

41. Radler $\mathrm{C}$. The Ponseti method for the treatment of congenital club foot: review of the current literature and treatment recommendations. Int Orthop 2013;37(9):1747-53. Crossref

42. Dobbs MB, Morcuende JA, Gurnett CA, Ponseti IV. Treatment of idiopathic clubfoot: an historical review. lowa Orthop J 2000;20:59-64.

43. MacNeille R, Hennrikus W, Stapinski B, Leonard G. A miniopen technique for Achilles tenotomy in infants with clubfoot. J Child Orthop 2016;10(1):19-23. Crossref

44. Faulks S, Richards BS. Clubfoot treatment: Ponseti and French functional methods are equally effective. Clin Orthop Relat Res 2009:467(5):1278-82. Crossref

45. Richards BS, Johnston CE, Wilson H. Nonoperative clubfoot treatment using the French physical therapy method. J Pediatr Orthop 2005;25(1):98-102.

46. Turgut A, Kalenderer Ö. Doğuştan çarpık ayakta yumuşak doku cerrahisi. TOTBID Dergisi 2015;14:208-13. Crossref

47. Macnicol M. Congenital Talipes Equinovarus (Clubfoot). In: Helal B, editor. Principles of Patient Care. Surgery of Disorders of the Foot and Ankle. London: Martin Dunitz; 1996. p.154.

48. Turco VJ. Surgical correction of the resistant club foot. One-stage posteromedial release with internal fixation: a preliminary report. J Bone Joint Surg Am 1971;53(3):477-97.

49. Carroll NC, McMurtry R, Leete SF. The pathoanatomy of congenital clubfoot. Orthop Clin North Am 1978;9(1):225-32.

50. Goldner JL. Congenital talipes equinovarus -fifteen years of surgical treatment. Curr Pract Orthop Surg 1969;4:61-123.

51. McKay DW. Dorsal bunions in children. J Bone Joint Surg Am 1983;65(7):975-80.

52. Simons GW. Complete subtalar release in club feet. Part II Comparison with less extensive procedures. J Bone Joint Surg Am 1985;67(7):1056-65.

53. Crawford AH, Marxen JL, Osterfeld DL. The Cincinnati incision: a comprehensive approach for surgical procedures of the foot and ankle in childhood. J Bone Joint Surg Am 1982;64(9):1355-8

54. Kalenderer O, Reisoglu A, Turgut A, Agus H. Evaluation of clinical and radiographic outcomes of complete subtalar release in clubfoot treatment. J Am Podiatr Med Assoc 2008;98(6):451-6.

55. Tümer $\mathrm{Y}, \mathrm{Uçar} \mathrm{DH}$. Pes Ekino Varus'un Yumuşak Dokulara Yapilan Cerrahisi. TOTBID Dergisi 2002;1(2):71-6.

56. Graham GP, Dent CM. Dillwyn Evans operation for relapsed club foot. Long-term results. J Bone Joint Surg $\mathrm{Br}$ 1992;74(3):445-8.

57. van Bosse HJ. Syndromic Feet: Arthrogryposis and Myelomeningocele. Foot Ankle Clin 2015;20(4):619-44. Crossref 